\title{
İlköğretim Okullarında Müzik Dersleri Nasıl Olmalı?
}

\author{
Süreyya Tezeren \\ Özel Asfa Eğitim Kurumları İstanbul Türkiye
}

\begin{abstract}
Özet
Bu çalışmada: Türkiye'deki ilköğretim okullarında, geçmişten günümüze kadar olan süreçte, müzik derslerinin nasıl işlendiği, öğrencilere kattığı değerler, derslerin veriliş biçimi, konu ile ilgili çeşitli örnek ve alıntılara yer verilerek, ele alınmıştır. Ayrıca, geçmişte verilen müzik eğitimi ve günümüzdeki uygulamalara yer verilerek karşılaştırmalar yapılmıştır. Genel bir bakış açısıyla; ülkemizde ilköğretim okullarında müzik eğitiminin yeterli düzeyde olmadığ 1 , çocuğun dünyasında hakettiği yeri işgal edemediği sonucuna varılmıştır. Müzik eğitiminin ilköğretim okullarında daha verimli hale getirilmesi için izlenmesi gereken eğitim politikaları ve yöntemler, örnekler verilerek, açıklanmıştır. Müzik eğitiminde en önemli unsurlardan birinin; öncelikle kendi geleneksel müziğimizi benimsetmek olduğu, bunu öğrencilere tanıtmanın öğrencinin perspektifini geliştireceği hususuna dikkat çekilmiştir. İdeal müzik eğitiminde başarıyı tetiklemede; sınıf öğretmeni, diğer branş öğretmenleri ve müzik öğretmeni arasında etkin bir senkronizasyonun sağlanması önemlidir. Ancak böyle bir koordinasyon ve senkronizasyon sağlanabilirse; "İdeal Ders Modeli” seviyesinde anlamlı bir standardı yakalamak mümkün olabilecektir. Etkili bir müzik eğitiminin, diğer derslerdeki başarıyı arttırdığı açıktır. Bunun sağlanması için, "müzik öğretmeni"nin; temel bilgilerin yanısıra, yeterli deneyime de sahip olması ve çerçevesinin temel kalite standartlarıyla çizilmiş olması gerektiği, çalışmada ayrıca vurgulanmıştır. Müzikte global yaklaşımdan uzaklaşmamak da önemlidir. Çalışmada; kendi müziğimizin global özelliğe sahip olduğu gerçeğini çocuğa benimsetecek bir eğitimin önemine değinilmiştir. Bununla beraber, müzik eğitiminde; kendi müziğimiz kadar, klasik batı müziği ve çeşitli ülkelerin etnik müziklerinin de, bir denge çerçevesinde öğretilmesi hususu göz ardı edilmemelidir.
\end{abstract}

Anahtar kelimeler: İlköğretim, müzik eğitimi, ideal ders modeli, global, senkronize

\section{Giriş}

Ülkemizde ilköğretim okullarında Cumhuriyetin ilk yıllarından itibaren verilmekte olan müzik dersleri amaçlanan hedefe ulaşamamıştır. Günümüze değin gittikçe deformasyona uğramış ve eğitimde gereken seviyeye ulaşamamıştır. Bu konuda ciddi bir açık doğmuştur. Bunun en önemli sebeplerinden biri, hazırlanan müfredat programlarının yetersizliği ve programların uluslararası kalite standartlarının altında uygulanmasıdır. Kendi geleneksel müziğimiz, müfredatın dışında tutulmuş, çok az yer verilse de amacına ulaşamamış ve müfredatta dayatılan batı müziği ise gerektiği standartlarda verilememiştir. Temel unsur, öğrencinin kendi geleneksel müziğini tanıyıp sevmesi ve global dünyada önemli bir yer işgal ettiğinin bilincine varmasıdır. Kendi müziği ile klasik batı müziği arasında köprü kurabilmeli, kendi müziğinin de yeterince global olduğu özgüvenini hissetmelidir.

Öğrencilere hem kendi müziğimiz, hem de klasik batı müziği düzeylerine uygun biçim ve dozda mutlak surette verilmelidir. Kendi kültür zenginliğinin gücünü hissederken, klasik batı müziği ve diğer ülke etnik müziklerini de özümsemiş birikime sahip olmalıdır.

Müzik eğitiminin çocuktaki sol beyin gelişimine, sosyal ve psikolojik gelişime olan katkıları sıklıkla gündeme getirilse de pratikte somut adımlar atılamamış veya yetersiz kalınmıştır.

İlköğretim sınıflarında verilen etkili müzik eğitimi ve eğitim dünyasına olan katkısı gelişmiş 
ülkelerde eğitim politikalarının mihenk taşıdır.

İlköğretim sınıfları müzik eğitiminde Müzik öğretmeni-sınıf öğretmeni ve diğer branş öğretmenleri ile senkronize çalışma esas alınmalıdır. Müfredat buna göre belirlenmeli ve müzik dersleri her sınıf düzeyinde belirlenen müfredat doğrultusunda ve sınıf öğretmeni, branş öğretmenleri senkronizasyonu çerçevesinde işlenmelidir. Sınıf öğretmeni tarafindan işlenen hayat bilgisi veya matematik dersi ile senkronize bir program sonucu ideal öğrenme modeli konusunda önemli adımlar atılmış olur. Öğrenciler bilgileri şark1-melodi-ritm denkleminde daha kolay ve zevk alarak öğrenirler. Burada ana husus merkeze alınan değerdir. Belirlenen senkronize müfredatta merkeze alınan değer, müzik öğretmeni ve diğer öğretmenler tarafından derste mutlaka vurgulanmalıdır. Bu yöntemle öğrenci bir yandan müziksel becerilerini geliştirirken, diğer yandan diğer branşlarla da bilgi akışı sağlanmaktadır.

\section{Yöntem}

Bu çalışma, betimsel (yazılı yada yazılı olmayan verilerin akıcı bir dil ve üslûp ile anlatılması, ortaya konması) bir alan araştırmasıdır.

$\mathrm{Bu}$ araştırmanın konusu ve kapsamı gereği yazımlanmış ve yazımlanmamış veri kaynaklarının her ikisinden de yararlanılmıştır. Bilirkişilerin görüşlerinin ve deneyimlerinin alınması kapsamında elde edilen bilgilerden yararlanılmıştır.Konu ile ilgili olarak İngilizce olarak yazılmış, İngilizce'ye çevrilmiş,Türkçe'ye çevrilmiş kaynaklardan elde edilen veriler, bulgular bölümünde kullanılmıştır. Türkiye'de yetişmiş çok değerli müzikolog ve sanatçılarla röportajlar yapılmıştır. Sözkonusu kişilerin söylemlerinden bazı çıkarımlara varılmıştır. Dijital ortamda yapılmış ve yayınlanmış anket ve araştırma sonuçlarından da yararlanılmıştır. Ayrıca öğretmen görüşlerine dayalı olarak yapılan bir araştırmadan faydalanılmıştır.

\section{Bulgular}

Yapılan araştırma ve anket sonuçlarına (Gazi üniversitesi 2001 - Ankara; Başbakanlık Aile ve sosyal araştırmalar Gn. Md. Ail eve toplum dergisi) göre ülkemizde İlköğretim okullarında verilen müzik eğitiminin yeterli olmadığı sonucuna varılmıştır.Geçmiş dönemlerde ilköğretim okullarında müzik dersleri sınıf öğretmenleri tarafından verilmiştir.Sınıf öğretmeninin müzik alanında akademik bir düzeye sahip olmaması sonucu verilen eğitim yetersiz kalmıştır.

Günümüzde müzik dersleri müzik öğretmenleri tarafından verilmektedir. Ancak altyap1 yetersizliği ile birlikte öğretmenlerin alanlarında yeterli donanıma sahip olmadıkları görülmektedir.

İlkokullardaki müzik eğitimiyle ilgili daha somut ve gerçekçi fikirler edinmek amaciyla öğretmen görüşlerine dayalı bir araştırma yapılmıştır. Araştırmaya Bursa merkez ilçelerindeki 20 ilköğretim kurumunda görev yapan 204 sınıf öğretmeniyle 20 müzik öğretmeni katılmıştır. Araştırmaya katılanlar rastlantısal yolla saptanmıştır.

Veri toplama aracı olarak, sınıf öğretmenleri ve müzik öğretmenleri için benzer iki anket formu uygulanmıştır. Araştırmaya katılan sınıf öğretmenleri, ilköğretim kurumları I.kademesinin her sinıfında görev yapmaktadırlar. (\% 20'si 1.sınıf, \% 20'si 2. sinıf, \% 18'I 
3.sınıf, \% 21'i 4. sınıf, \% 21'i 5. sınıf öğretmenidirler.) Böylece örneklemi oluşturan öğretmenlerin farklı yaş ve sınıflardaki öğrencilere ilişkin tecrübelere sahip oldukları anlaşılmaktadır. Müzik öğretmenleri de \% 80’i 4.ve 5. sınıflarda bizzat ders vererek diğerleri de çeşitli çalışmalarla birinci kademe eğitiminin içinde yer almaktadırlar.

Ayrıca her iki grup öğretmenin büyük bir bölümü (sınıf öğretmenlerinin \% 80’i, müzik öğretmenlerinin \% 50'si) 25-30 ders saatlik bir ders yükü ile görevlerini sürdürdüklerini belirtmişlerdir. Bir başka deyişle araştırmaya katılan öğretmenler birbirine benzer bir ders yükü sorumluluğuna sahiptirler.

Sınıf öğretmenlerinin \% 46'sı, ilköğretim I.kademedeki müzik derslerinin başarılı bir biçimde yürütülemediğini, diğer \% 45,6's1 da "kısmen" gerçekleştirildiğini belirtmişlerdir (Tablo 5). Müzik öğretmenlerinin \% 55’i ise, müzik derslerinin "kısmen" gerçekleştirilebildiği görüşünde birleşmişlerdir.

http://dergipark.gov.tr/download/article-file/153345

Tablo 1: Müzik Derslerinin Uygulamadaki Başarısı

\begin{tabular}{|c|c|c|c|c|}
\hline \multirow{3}{*}{$\begin{array}{c}\text { Başarı } \\
\text { Durumu }\end{array}$} & \multicolumn{4}{|c|}{ Öğretmenler } \\
\hline & \multicolumn{2}{|c|}{ Sınıf Öğretmenleri } & \multicolumn{2}{|c|}{ Müzik Öğretmenleri } \\
\hline & $f$ & $\%$ & $f$ & $\%$ \\
\hline Evet & 15 & 07.35 & 03 & 15.00 \\
\hline Kismen & 93 & 45.59 & 11 & 55.00 \\
\hline Hayır & 94 & 46.08 & 05 & 25.00 \\
\hline Başka & 02 & 00.98 & 01 & 05.00 \\
\hline TOPLAM & 204 & 100.00 & 20 & 100.00 \\
\hline
\end{tabular}

$\mathrm{Bu}$ görüşlerin nedeni sorulduğunda, sınıf öğretmenlerinin \% 67'si “sınıf öğretmenlerinin yeterli birikime sahip olmamaları"nı göstermişlerdir. Müzik öğretmenlerinin de \% 30'u aynı nedeni gösterirken, sınıfların kalabalık olmasını (\% 20 oranında) ve 1-4. sinıflarda müzik dersinin süresinin az olmasını da (\% 25 oranında) neden olarak belirtmişlerdir.

Bilirkişi görüşlerinde ise kendi müziğimizin eğitimde temel alınması esastır. Hollandalı müzikolog Walter Schweiz in bir ifadesi vardır. Der ki, dünyada iki tane klasik müzik vardır. Bir tanesi klasik Batı müziği, diğeri de bütün şark’1 temsil ile Köklü klasik Türk müziği. Walter Schweiz bunu söylediği, halde maalesef birtakım yetersiz görüşler şartlanmış ve hatta diyebilirim ki satılmış görüşler doğrultusunda Klasik Türk musikisinin ne kadar ulvi ne kadar önemli ne kadar özel bir açığa çıkış olduğunu, bir estetik olduğunu anlayamayan insanlar tarafından yasaklanmış ve de netice itibariyle milletin gözünden düşürülmüştür. Kültür kopuşu eğitimde boşluk oluşmasına sebep olmuştur. (A.Özhan-2018-67)

Dünyada iki medeniyet müziği var Biri 400 senedir Batı'nın ortaya çıkardığı medeniyetin 
müziği olan Klasik batı müziğidir. Klasik batı müziği öncesinde bu topraklarda oluşan bir medeniyet müziği var. Tandanslı makam müziği. Her iki müzikten de örnekler sunabiliriz ama sunduğumuz örneklerin efsafi önemlidir. Noktrin dinletileceği gibi, Ay Işı̆̆ı Sonatı da dinletilmelidir. Çocuklarda dinleti etkisi çok önemlidir. Müziği öğretirken sevdirmek esastır. (Kaan Ulaş-2018-48)

\section{Sonuçlar}

İlköğretim okullarında müzik dersleri öğrenciye sevdirilerek işlenmelidir. Müziği sevdirmede dinletiler önemli bir yer tutar. Öğretim,konuların masalsı biçimde anlatımı ile gerçekleştirilmelidir.

Eğitici dinletilere her sınıf düzeyinde beş altı dakika kadar yer verilmelidir. İdeal zaman dilimi dersin ilk beş dakikasıdır. Bu süre içinde öğrenciye gözü kapalı ve relax bir konumda müzik dinletilmeli ve bir hayal kurması istenmelidir. Daha sonra öğrencinin yaş seviyesine uygun biçimde dinlediği müzik kritize edilmelidir. Öğrenci duyduğu müziği ifade edebilmeli, yorumda bulunabilmeli ve kendisinde yarattığı olumlu etkiyi dile getirebilmelidir. Öğrenci bu yöntemle hem kendi müziğini ve geleneksel enstrümanları tanırken, dünya müziğini ve enstrümanlarını da içselleştirerek öğrenir. Yeni müfredatta geleneksel müziğimize ait konulara geniş biçimde yer verilmiştir olmakla birlikte kilit nokta, müzik öğretmeninin konuyu etkili biçimde uygulamaya koyabilmesi ve disiplinler arası bütünlük sağlanabilmesidir. Dinleme eğitimi sonrasında öğrencilerin etkili soru sormaları sağlanmalıdır. Güzel soru sormayı öğrenen öğrenci daha kolay ve etkili öğrenir.Ayrıca müzik derslerinde görsel öğeler ve videolara geniş yer verilmelidir. Kritik ve analitik düşünme yöntemleri derslerde aktif olarak uygulanmalıdır.

Ritm, müziğin vazgeçilmez öğesidir. Öğrenciler anasınıflarından itibaren ritm çalgıları ile tanış olurlar. Ritm enstrümanları ile yaptırılan çalışmalarda matematik dersi ile köprü kurmaları sağlanmalıdır. Nota değerleri çalınan ritmler yolu ile verilebilir. Öğrenci ritm aletini kullanırken nesne-sayı ilişkisi ile hem ritm becerisini hem de matematiksel beceriyi geliştirir. Böylelikle disiplinler arası bağlantı sağlanmış olur.

Her çalışma sonunda öğrenci ile çalışmanın amacı kritize edilir. Verilen eğitimin kazanımları öğrenci tarafından ifade edilir. Öğrencilerin soru sormaları için zemin hazırlanır.

Şarkı söyleme ise doğru ses kullanımını öğretmede en eğlenceli araçtır. Diğer branş dersleri ile bilgi akışı sağlamada ise mükemmel bir materyaldir.

Öğrenci, öğrendiği şark1 yoluyla kendi müziğini, yöresini ve sosyal yaşamı tanır. Tarihini öğrenir. Şarkı eğitiminde öğrenciye müzik yolu ile birçok bilgi kazandırılmalıdır. Şarkının amacı,içeriği ve öğretilme sebebi öğrenciye kritik ve analitik düşünme yöntemleri ile hissettirilmelidir. Öğrencilerin severek okudukları bazı şiirler besteleme yolu ile şarkı haline getirilir. Bilinen eserlerin yanısıra,müzik öğretmenleri özgün besteler yaparak derslere ambians katılmalıdır.

Şarkı eğitimi müzik derslerinin temel taşıdır. Şarkı çalışmaları, sınıf koroları ve okul koroları ile hiyerarşik bir çizgide geliştirilmelidir. Öğrenci, emeğini toplum önünde sergileyebilmelidir. Bir koroda görev almak, gurup içinde sorumluluk alma ve toplum önünde en iyi performansı sergileme ve sonunda onore olma duygusu son derece değerli bir kazanımdır. 
Bu noktada müzik öğretmenine önemli bir rol düşer. Müzik öğretmeni eğitimci konumunun yanısıra 'müzisyen' olma niteliği taşımalıdır. İyi bir müzik eğitmeni iyi bir müzisyen olmak zorundadır. Yeterli enstrüman çalma becerisine ve sesini etklili kullanma becerisine sahip olmalıdır. Ülkemizdeki ilköğretim müzik eğitimindeki en önemli sorunlardan biri, müzik öğretmenlerinin çoğunun enstrüman çalma konusunda yeterli standartlarda olmamasıdır. Öncelikli amaçları sanatçı yetiştirmek olmadığı için eğitim fakülteleri müzik bölümlerinde enstrüman derslerine gereken önem verilmemektedir.( kişisel çabalarıyla kendilerini geliştiren öğretmen adayları hariç) Konservatuar mezunu müzik öğretmenleri ise 'sanatçı' kriterlerine göre yetiştirildikleri için enstrüman çalma ve sesini etkili kullanma noktasında yeterli standartlara sahip olmakla birlikte öğretmenlik mesleğini severek yapmaları ve pedagojik anlamda tecrübe kazanmaları büyük önem taşır.Akademik anlamda yeterli standartlara sahip bir müzik öğretmeni, mesleğini severek ve isteyerek icra ettiği takdirde başarılı bir çizgiye gelebilir.

Günümüzde müzik dersleri 40 dakikalık zaman dilimi ile sınırlıdır. Mevcut süre enstrüman eğitimi için yetersizdir. Bire-bir veya grup eğitimi ile gerçekleşmesi mümkün olan enstrüman eğitimi için okullarda yetenek gelişim dersleri mutlak surette uygulanmalıdır. Dersler, konusunda uzman ve yeterli kriterlere sahip öğretmenler tarafından verilmelidir. Öğretmenin hem pedagojik hem de akademik yönü güçlü olmalıdır. Öğrenciye enstrüman çalmanın sağladığı kazanımlar sürekli biçimde hissettirilmelidir. Enstrüman çalmak geçici bir heves olarak değil, faydalı ve keyifli bir sanatsal aktivite olarak benimsetilmelidir. Öğrenciye enstrüman öğrenmenin ciddi ve emek gerektiren bir uğraş olduğu kadar, keyifli ve ayrıcalıklı bir çalışma olduğu hissettirilmelidir. Enstrüman eğitiminde pedagojik yaklaşım çok önemlidir. Öğrenci genellikle enstrüman çalmaktan vazgeçmez. Vazgeçme sebebi, büyük ölçüde öğretmen yaklaşımıdır. Öğrencinin mevcut koşullarına uygun biçimde ve özendirici unsurlar katarak yapılan enstrüman eğitimi, öğrenci için değerli bir kazanımdır.

\section{Referanslar}

Afsin, K (2005) Comprendre la I'ecoute musicale pour faire apprendre la musigue Suisse:Revue musicale suisse

Afsin, K (2009) Psychopedagogie de' ecoute mucicale Bruxelles: Editions De Boeck Universite Americans Love Makings Music - And Value Mucic EducationMore Highly Than Ever American Music Conference (2000) B. Friedman(1959) "An Avalution of The Achievement of Readingand andArithmetic (2002) B. Friedman(1959) Artan, İ., Balat, G.U (2001) Kastamonu Eğitim Dergisi, Artan, İ., (1993) Ankara Başbakanlık Aile ve Sosyal Araştırmalar Gn. Md. Aile ve Toplum Dergisi. 